\title{
Analysis of Retorted Water Produced from Partial Combustion of Sultani Oil Shale
}

\author{
Sura Al-Harahsheh1', Omar Al-Ayed2', M. Amer³, M. Moutq2 \\ ${ }^{1}$ Institute of Earth and Environmental Sciences, Al al-Bayt University, Mafraq, Jordan \\ ${ }^{2}$ Department of Chemical Engineering, Al-Balqa Applied University, Amman, Jordan \\ ${ }^{3}$ Department of Chemistry, Jordan University, Amman, Jordan \\ Email:surah_h71@yahoo.com,omar.alayed@bau.edu.jo,Momer@ju.edu.jo,Matouqu3@yahoo.com
}

How to cite this paper: Al-Harahsheh, S., Al-Ayed, O., Amer, M. and Moutq, M. (2017) Analysis of Retorted Water Produced from Partial Combustion of Sultani Oil Shale. Journal of Environmental Protection, 8, 1018-1025.

https://doi.org/10.4236/jep.2017.89064

Received: May 18, 2017

Accepted: August 22, 2017

Published: August 25, 2017

Copyright $\odot 2017$ by authors and Scientific Research Publishing Inc. This work is licensed under the Creative Commons Attribution International License (CC BY 4.0).

http://creativecommons.org/licenses/by/4.0/

\begin{abstract}
Oil shale samples from Sultani oil shale mine, south of Jordan, were pyrolyzed by a partial combustion to generate shale oil. The produced water was sent for analysis. The different samples were analyzed for carbon content, and results showed that the TOC was $2010 \mathrm{mg}$ per liter of retorted water. Phenol and arsenic contents were measured and found to be $64 \mathrm{mg}$ and $0.18 \mathrm{mg}$ per liter respectively. Phosphate and sulfate were also determined and found to be 35.7 and $5022 \mathrm{mg}$ per liter. On the other hand, ammonium was also found to be $2831 \mathrm{mg}$ per liter. Several elements were traced and reported in the present work, in which arsenic, chrome and nickel are the most important, and the retorted water was found to contain $0.18,0.7$ and $0.5 \mathrm{mg}$ per liter.
\end{abstract}

\section{Keywords}

Retorted Water, Partial Combustion, Oil Shale, Sultani

\section{Introduction}

Water is necessary for producing shale oil. The amount and quality vary with technology. Typical uses include process cooling, reclamation, and dust control. The municipal needs result from any population increase due to oil shale workers and supporting businesses.

Water is produced during the processing (retorting) of oil shale that is not indigenous or tributary to local ground water or streams. It amounts to between 4 and $14 \%$ of the shale oil produced. Therefore an average of $10 \%$ of the required indigenous water may be saved by treating this water and using it within the project [1].

Oil shale retorted water is produced due to pyrolysis and/or combustion of oil 
shale. As a result of these processes, water liberated from clay, intermolecular water, and chemical reaction waters are termed retorted waters. The oil shale retorting process is unique, as the resulting wastewater contains large amounts of oil, sulfide, cyanide, volatile phenol, ammonia, and other toxic substances; it has high content of COD and refractory material and more [2]. Wastewater discharged from a retorting plant [3] contains oil, suspension solids, and oxygen nitrogen, and sulfur compounds. It can be treated by sedimentation, oil interception, flocculation, air flotation, and biological treatment.

All liquid effluents from the oil shale thermal treatment plants consist of three wastewater streams [4]: Process water containing physically and chemically bound waters, industrial wastewater, and leachate containing different dissolved pollutants, such as phenols and mineral salts.

Earlier investigators [5] have reported fifty percent of the dissolved organic carbon was identified as specific compounds in both retort wastewaters. In the processed retort wastewater, 42 percent of the dissolved organic carbon is consisted of a homologous series of fatty acids from $\mathrm{C}_{2}$ to $\mathrm{C}_{10}$. Dissolved organic-carbon for the other compound classes were: aliphatic dicarboxylic acids; phenols; hydroxypyridines; and aliphatic amides. In the gas-condensate retort wastewater, aromatic amines were most abundant at 19.3 percent [5] of the dissolved organic carbon, followed by phenols, nitriles, aliphatic alcohols aliphatic ketones, and lactones. Steam volatile organic solutes were enriched in the gas-condensate retort wastewater, whereas nonvolatile acids and polyfunctional neutral compounds were predominant organic constituents of the processed retort wastewater.

Thiosulfate and thiocyanate were major constituents in four retort wastewaters derived from combustion-type processing of oil shale. Thiosulfate was the predominant sulfur species with concentrations ranging from 420 to 2200 milligrams per liter. Thiocyanate concentrations ranged from 24 to 720 milligrams per liter [5].

In this work, the oil shale sample was taken from Sultani mine and subjected to partial combustion to retortoil shale to produce shale oil without external heating source. During this process, a large amount of water is produced due to dissociation of the different forms of water from mineral content present in the oil shale and generated in the combustion process and pyrolysis. With the available equipment, we have tried to identify the different pollutant and contaminants of the retorted water.

\section{Experimental Procedure}

The oil shale from the Sultani mine is crushed and sieved to $10-50 \mathrm{~mm}$ size using ASTM standards. The retort is a $50 \mathrm{~cm}$ diameter and $120 \mathrm{~cm}$ long unit. The retort is designed to facilitate initial heating through an external source until the temperature of the oil shale is high enough to initiate auto ignition of the shale. The temperature of retort was monitored and measured through different 
thermocouples located at different position of the oil inside the retort. The maximum temperature achieved in the retort was $600^{\circ} \mathrm{C}$ which is reported in the combustion region below the pyrolysis section of the retort. The retort is equipped with a suction system and condensing heat exchanger to withdraw generated gases and condense the hydrocarbon respectively.

Several runs were conducted on the retort with each run sample size varying between $30 \mathrm{~kg}$ to $50 \mathrm{~kg}$ of sample. The collected liquid is taken for decantation, where water is withdrawn from the bottom of the vessel. The same sample of water was distributed into different smaller samples and sent for analysis.

The experimental set up is shown in Figure 1. The main sections of the unit are the body of the retort, inlet feeding system, heat exchange, and ash discharging outlet.

\section{Results and Discussion}

The retort was operated mainly to generate shale oil for calculating the yield, and analyzing and characterizing the produced shale oil. The produced water was considered as a secondary byproduct, where it was taken for analysis to identify the different contaminants due to the pyrolysis and combustion processes. These pollutants are hydrocarbon and mineral sourced components.

The oil yield which is based on Fischer assay calculations was not calculated, due to excessive burning although simple calculations show that it is close to $50 \%$. Table 1 shows the results of elemental analysis of Sultani oil shale sample which is employed in this work.

The produced water from retorting oil shale contains dissolved, suspended solids, organic compounds, inorganic materials, and hydrogen sulfide. In general, the retorted water is found to contain several compounds such as: Phenols, sulfate, Chlorides, Nitrogen, phosphorus, Oil Products, Suspended Solids, Alcohol, ketones, aldehydes, lactones, pyrrole, Dissolved Organic Carbon, Carboxylic Acids, Formic acid, Acetic acid, Benzoic acid, Toluene, Hydroxyl Benzene, Aromatic Amines, Aniline, Amine, Pyridine, Quinoline, Amide, Nitriles, Ammonia, Carbonates, Thiocyanate, Nitrate, Copernicium, Arsenic, Zinc, Chromium,


Figure 1. The different main sections of the experimental setup. 
Table 1. Elemental analysis of sultani oil shale.

\begin{tabular}{cccccc}
\hline Item & $\begin{array}{c}\text { Carbon } \\
\text { wt. \%. }\end{array}$ & Hydrogen wt. \% & Nitrogen wt. \% & $\begin{array}{c}\text { Sulfur } \\
\text { wt. \% }\end{array}$ & $\begin{array}{c}\text { Calorific Value, } \\
\mathrm{kJ} / \mathrm{kg}\end{array}$ \\
\hline 1 & 76.325 & 9.300 & 1.43 & 11.388 & 34,200 \\
2 & 77.725 & 9.422 & 1.367 & 10.94 & 39,558 \\
\hline
\end{tabular}

Lead, Iron, Bromine, Cadmium, Silver, Mercury, Scandium, Boron, Barium, Copper, Molybdenum, Fluorine, cesium, Tin, Ruthenium, Aluminum, manganese, indium, iodine, antimony, tungsten, zirconium, Cerium, vanadium, yttrium, europium, dysprosium and lutetium, hydrogen sulfide, carbon dioxide, Calcium, Magnesium, Potassium, Sodium, Fluoride, Organic carbon.

Since it is desired to investigate the presence of some of these earlier mentioned chemical compounds, the test performed in this research work for the selected component is dictated by the availability of the equipment capable of detecting and measuring these chemicals.

In the coming section, each investigated material will be discussed with respect to the equipment used, place of conducting these tests, and the results obtained.

\subsection{Total Organic Carbon (TOC)}

The term TOC indicates total organic carbon presenting in retorted water. This test reports the total organics, with identification of the chemical formula and type. This investigation's work is performed in Dar Al Dawa Company laboratories. Analytical technologies utilized to measure TOC share the objective of completely oxidizing the organic molecules in a liquid of sample water to carbon dioxide $\left(\mathrm{CO}_{2}\right)$, measuring the resultant $\mathrm{CO}_{2}$ concentration, and expressing this response as carbon concentration. All technologies must differentiate between the inorganic carbon, which may be present in the water, from sources such as the ones dissolved $\mathrm{CO}_{2}$ and bicarbonate, and the $\mathrm{CO}_{2}$ generated from the oxidation of organic molecules in the sample. One approach used to measure TOC involves subtracting the measured inorganic carbon (IC) from the measured total carbon (TC), which is the sum of organic carbon and inorganic carbon:

$$
\text { TOC }=\text { TC }- \text { IC }
$$

In Dar $\mathrm{Al}$ Dawa laboratories, Elemental equipment was used to estimate the TOC in the retorted water specimen. The test results from the water sample have shown that the water contained $2010 \mathrm{mg}$ per liter of TOC. Dobson et al. in their study of Rundle oil shale have reported 5000 ppm of TOC material in their workemploying GC for analysis. The water sample was taken from Fischer Assay apparatus. In a different study reported by Syamsiah et al. the retorted water was found to contain more than 13,000 $\mathrm{mg} /$ liter. In another work of [6], Venardos and Grieves reported $1800 \mathrm{mg} /$ liter in their study of in-situ and normal retorting. In a similar study by AlJaradin [7] it retorted water obtained from Ellajjun oil shale, it is found to contain $3270 \mathrm{mg} / \mathrm{liter}$. As presented earlier, the present water sample contains comparable TOC quantity as compared and reported by 
other investigators. This difference is due to the difference in experimental conditions and nature of the oil shale sample. It is clear from the reported numbers that the retorted water contain large quantity of TOC, and it is apparent from these numbers that the water content of TOC is dependent on oil shale location and type, and may be to a large extent on the operation conditions of extracting shale oil.

\subsection{Phenol}

Phenol is a colorless-to-white solid when pure; however, the commercial product, which contains some water, is a liquid. Phenol has a distinct odor that is sweet and lasting. Most people begin to smell phenol in the air at about 40 parts of phenol per billion parts of air (ppb), and they begin to smell phenol in the water at about $1-8$ parts of phenol per million parts of water. These levels are lower than the levels at which adverse health effects have been observed in animals that breathed air containing phenol, or drank water containing phenol. Phenol evaporates more slowly than water, and a moderate amount can form a solution with water.

A number of effects from breathing phenol in the air have been reported in humans. Short-term effects reported include: respiratory irritation, headaches, and burning eyes. Chronic effects of high exposures included: weakness, muscle pain, anorexia, weight loss, and fatigue; effects of long-term low-level exposures included: higher chance of developing respiratory cancer, heart disease, and effects on the immune system.

The retorted water content of phenol was determined in Dar Al Dawa laboratories using HPLC. The tested water was found to contain $64 \mathrm{mg} / \mathrm{liter}$. A study by AlJaradin retorted water obtained from Ellajjun oil shale retorting has reported $29 \mathrm{mg} /$ liter. A similar study by Venardos et al. has reported $14.2 \mathrm{gm} / \mathrm{liter}$ of phenol in retorted water obtained from in-situ and above ground retorting. The test is performed on a sample and repeated three times. Dobson et al. [8] reported $105 \mathrm{mg} / \mathrm{liter}$ in Rundle oil shale retorted water. Syamsiah et al. [9] reported $25 \mathrm{mg} /$ liter during their analysis of the retorted water. On the other hand, Kekisheva et al. [10] investigated the retorted water and found $1500-2000$ $\mathrm{mg} /$ liter content of phenol. Harold et al. [11] reported phenol content equal to $54.3 \mathrm{mg} /$ liter in their study on oil shale from Utah.

It can be seen that the phenol content of Sultani oil shale is comparable with Utah oil shale, and less than that reported by Kekisheva et al. [10]. Other studies, as mentioned earlier, have values higher than or less than found in Jordanian oil shale.

\subsection{Arsenic Metal}

Long-term exposure to arsenic in drinking water can cause cancer in the skin, lungs, bladder, and kidney. It can also cause other skin changes such as thickening and discoloration. The likelihood of effects is related to the level of exposure 
to arsenic and in areas where drinking water is heavily contaminated, these effects can be seen in many individuals in the population. Increased risks of lung and bladder cancer and skin changes have been reported in people ingesting arsenic in drinking water at concentrations of $50 \mu \mathrm{g} / \mathrm{liter}$, or even lower.

Exposure to arsenic in the workplace by inhalation can also cause lung cancer. The likelihood of cancer is related to the level and duration of exposure. Increased risks of lung cancer have been observed at exposure levels that add up to more than $750\left(\mu \mathrm{g} / \mathrm{m}^{3}\right)$ yearly.

In regards to the possible method by which arsenic causes cancer, the evidence in humans indicates that arsenic can cause damage to whole chromosomes, but it does not appear to cause damage to the individual genes.

The metal arsenic, abbreviated as As, was detected in serval oil shale retorted water samples. In the present work, the amount of Arsenic metal was found to be $0.18 \mathrm{mg} /$ liter. AlJardain [7] reported $0.23 \mathrm{mg} /$ liter arsenic content of the retorted water obtain from Ellajjun oil shale deposits. Matouq et al. [12] have reported $0.15 \mathrm{mg} / \mathrm{liter}$ for water obtained from Ellajjun oil shale retorting. These authors have used Inductively Coupled Plasma Mass Spectrometer. The Inductively Coupled Plasma/Atomic Emission Spectrometry of the Water Authority of Jordan laboratories was used to detect and measure the metal content. Venardos et al. have reported, in a similar work, a value of $0.133 \mathrm{mg} / \mathrm{liter}$. The result reported by this work is comparable with the one reported by Venardos et al.

\subsection{Phosphate}

After a thorough review on phosphate related literature, it is reported that excessive phosphate consumption leads to a higher mortality rate in patients with renal disease. Free phosphate, as found in food additives, is entirely absorbed in the gastrointestinal tract, and research has demonstrated that individuals with renal disease have significant concentrations of elevated phosphate. Recent studies have demonstrated that phosphate also seems to damage blood vessels and induce aging processes. Many types of fast food contain phosphate additives, and fast foods are generally predominately consumed by those of lower socioeconomic status. It also appears that excessive phosphate consumption is associated with increased prevalence of cardiovascular diseases in the general population.

Tests were performed in Stannous chloride reported $35.7 \mathrm{gm} / \mathrm{liter}$ in the present work. While Dean et al. [13] have reported $852 \mathrm{mg} /$ liter as phosphorous. Despite the Jordanian oil shale being located close to phosphate mines in south of Jordan, the reported values are small compared with other studies.

\subsection{Sulfate}

Sulfate is a substance that's found naturally in drinking water. Health concerns regarding sulfate in drinking water have been raised because of reports that diarrhea may be associated with the ingestion of water containing high levels of 
sulfate. Groups within the general population that may be at greater risk from the laxative effects of sulfate when they experience an abrupt change from drinking water with low sulfate concentrations to drinking water with high sulfate concentrations are of particular concern. Sulfate in drinking water currently has a secondary maximum contaminant level (SMCL) of 250 milligrams per liter $(\mathrm{mg} / \mathrm{L})$, based on aesthetic effects (i.e., taste and odor).

The test equipment for determining sulfate in the present work is Ion Chromatography in Jordan Water Authority laboratories. The reported value is 5022 $\mathrm{mg} /$ liter for retorted water obtained from retorting Sultani oil shale. A similar study by Matouq et al. [12] found that the retorted water contains $1500 \mathrm{mg} / \mathrm{liter}$. Rundle oil shale retorted water was found to contain $1916 \mathrm{mg} / \mathrm{liter}$ reported by Daniel et al. [14]. In other similar work, $180 \mathrm{mg} / \mathrm{liter}$ was reported by Kekisheva et al. As it is seen from the reported values, that Jordanian oil shale contains large amount of sulfate which can be ascribed to the nature of Jordanian oil shale.

\section{References}

[1] http://www.oilshaleassoc.org/ natosa@comcast.net accessed on 1-9-2015.

[2] Wang, S. , Dai, X. and Sun, Y. (2011) Study on the Treatment of Wastewater of Oil Shale Retorting by Photocatalytic Degradation with $\mathrm{TiO}_{2}$. International Conference on Remote Sensing, Environment and Transportation Engineering (RSETE), Nanjing, 24-26 June 2011.

[3] Wan, J.Q. (2002) Environmental Impacts of Oil Shale and Pollution Control Technologies. Coal, Oil Shale, Natural, Bitumen, Heavy oil and Peat-Vol. II. Environmental Impact of Oil Shale and Pollution Control Technologies.

[4] Kamenev, I., Munter, R. and Pikkov, L. (2003) Wastewater Treatment in Oil Shale Chemical Industry. Oil Shale, 20, 443-457.

[5] Leenheer, J.A. and Noyes, T.I. (1986) Effect of Organic Wastes on Water Quality from Processing of Oil Shale from the Green River Formation, Colorado, Utah and Wyoming. US. Geological Survey Professional Paper.

[6] Venardos, D.G. and Grieves, C.G. (1985) Oil Shale Retorting and Retort Water Purification Process. US4495056 A.

[7] Aljaradin, M. (2012) Comparison of Retort Water Treatment Methods-A Case Study in Jordan. VATTEN-Journal of Water Management and Research, 68, 37-41.

[8] Dobson, K.R., Stephenson, M., Greenfield, P.F. and Bell, P.R.F. (1985) Identification and Treatability of Organics in Oil Shale Retort Water. Water Research, 19, 849-856. https://doi.org/10.1016/0043-1354(85)90142-3

[9] Syamsiah, S., Krol, A., Sly, L. and Bell, P. (1993) Adsorption and Microbial Degradation of Organic Compounds in Oil Shale Retort Water. Fuel, 72, 855-861.

https://doi.org/10.1016/0016-2361(93)90092-G

[10] Kekisheva, L., Smirnov, I., Ostroukhov, N., Petrovich, N., Sitnik, V., Riisalu, H. and Soone, Yu. (2007) The Influence of Phenols and Other Compounds on Chemical Oxygen Demand (COD) of Phenolic Waters from the Kiviter Process. Oil Shale, 24, 573-581.

[11] Stuber, H.A., Leenheer, J.A. and Farrier, D.S. (1978) Inorganic Sulfur Species in Waste Waters from in Situ Oil Shale Processing. Journal of Environmental Science and Health. Part A: Environmental Science and Engineering, 13, 663-675. 
[12] Matouq, M., Al-Ayed, O., Al-Anber, Z., Al-Shannag, M., Kloub, N., Tagawa, T. and Aljbour, S. (2010) The Treatment of Wastewater Resulted from Oil Shale Retorting with High Frequency Ultrasound Waves. Energy Sources, Part A: Recovery, Utilization, and Environmental Effects, 32, 1878-1884. https://doi.org/10.1080/15567030902842202

[13] Venardos, D.G. and Grieves, C.G. (1986) Oil Shale Retorting and Retort Water Purification Process. US 4585063 A.

[14] Daniel, A.N. and Francis, P.M. (2006) Petroleum and Liquid Fossil Fuels Analysis. John Wiley \& Sons, Hoboken.

Submit or recommend next manuscript to SCIRP and we will provide best service for you:

Accepting pre-submission inquiries through Email, Facebook, LinkedIn, Twitter, etc. A wide selection of journals (inclusive of 9 subjects, more than 200 journals) Providing 24-hour high-quality service

User-friendly online submission system Fair and swift peer-review system Efficient typesetting and proofreading procedure Display of the result of downloads and visits, as well as the number of cited articles Maximum dissemination of your research work

Submit your manuscript at: http://papersubmission.scirp.org/ Or contact jep@scirp.org 